\title{
Scientific literacy: a key part of school contexts
}

\section{Alfabetização científica: uma parte fundamental dos contextos escolares}

\section{Alfabetización científica: una parte clave de los contextos escolares}

\author{
Stefanny Colonia Cerna ${ }^{1}$ iD , Doris Fuster-Guillén ${ }^{2}$ iD , Angélica Sánchez Castro ${ }^{3}$ iD,
} Hugo Wálter Maldonado Leyva4 iD, Teodoro Víctor Cabezas Ramírez ${ }^{5}$ iD

\footnotetext{
${ }^{1}$ Universidad Nacional Mayor de San Marcos, Lima, Perú.

${ }^{2}$ Universidad Privada San Juan Bautista, Lima, Perú.

${ }^{3}$ Universidad Tecnológica del Perú, Lima, Perú.

${ }^{4}$ Universidad Nacional Santiago Antúnez de Mayolo, Lima, Perú.

${ }^{5}$ Universidad Peruana Los Andes, Lima, Perú.
}

\section{Corresponding author:}

Stefanny Colonia Cerna

Email: stefanny.colonia@unmsm.edu.pe

How to cite: Colonia, S. C., Fuster-Guillén, D., Castro, A. S., Leyva, H. W. M., Ramírez, T. V. C. (2021). Scientific literacy: a key part of school contexts. Revista Tempos e Espaços em Educação, 14(33), e15611.

http://dx.doi.org/10.20952/revtee.v14i33.15611

\begin{abstract}
The work conducted a bibliographic review on alphabetization scientific, which is understood as the ability to use scientific knowledge in order to understand and help make decisions about the actual world. It also sought to explain the evolution of the dimensions of scientific literacy and to present theoretical proposals for methodological strategies to help improve it. Articles, doctoral theses and PIS test reports were reviewed to reach two conclusions: 1 ) it is essential to develop the four dimensions of scientific literacy, because, in this way, scientifically literate students will be trained; that is, they are able to become world that goes through constant scientific and technological and 2 ) it is necessary to update the teaching-learning strategies by those that are part of the so-called active methodology such as discovery learning, research-based learning and project-based learning.
\end{abstract}

Keywords: Methodological strategies. Natural sciences. Scientific literacy.

\section{RESUMO}

O trabalho realizou uma revisão bibliográfica sobre a betização alfacientífica, entendida como a capacidade de utilizar o conhecimento científico para compreender e auxiliar na tomada de decisões sobre o mundo atual. Procurou também explicar a evolução das dimensões da literacia científica e apresentar propostas teóricas de estratégias metodológicas para ajudar a melhorá-la. Artigos, teses de doutorado e relatórios de provas do PIS foram revisados para se chegar a duas conclusões: 1) é 
fundamental desenvolver as quatro dimensões da alfabetização científica, pois, dessa forma, os alunos alfabetizados cientificamente serão formados, ou seja, poderão se tornar um mundo que atravessa constante cambios científicos e tecnológicos e 2) é necessário atualizar as estratégias de ensino-aprendizagem por aqueles que fazem parte da chamada metodologia ativa, como aprendizagem por descoberta, aprendizagem baseada em pesquisa e aprendizagem baseada em projetos.

Palavras-chave: Ciências naturais. Estratégias metodológicas. Literacia científica.

\section{RESUMEN}

El trabajo realizó una revisión bibliográfica sobre alfabetización científica, entendida como la capacidad de utilizar el conocimiento científico para comprender y ayudar a tomar decisiones sobre el mundo real. También buscó explicar la evolución de las dimensiones de la alfabetización científica y presentar propuestas teóricas de estrategias metodológicas para ayudar a mejorarla. Se revisaron artículos, tesis doctorales e informes de pruebas del PIS para llegar a dos conclusiones: 1) es fundamental desarrollar las cuatro dimensiones de la alfabetización científica, porque de esta manera se formará a los estudiantes científicamente alfabetizados; es decir, podrán convertirse en un mundo que atraviesa constantes cambios científicos y tecnológicos y 2) es necesario actualizar las estrategias de enseñanza-aprendizaje por parte de aquellas que forman parte de la denominada metodología activa como son el aprendizaje por descubrimiento, el aprendizaje basado en la investigación y el aprendizaje basado en proyectos.

Palabras clave: Alfabetización científica. Ciencias naturales. Estrategias metodológicas.

\section{INTRODUCTION}

Society increasingly faces different issues related to science; for this reason, Diaz (2019) points out that, in recent years, one of the reasons for the teaching of science is to reach a scientifically literate population; that is, today, to be able to make informed decisions.

At the national and international levels, various research has been carried out on the basis of scientific literacy that has revealed problems in developing this capacity in students, demonstrating that the objective set by Díaz (2019) is not being met; example of this was the research carried out by Mendoza and Barreto (2017) which showed that, in an educational institution in Colombia, $86.54 \%$ of students do not draw conclusions and predictions from information derived from scientific research, nor does it recognize patterns and regularities in the data derived from scientific research nor does it represent information from different contexts. Another case occurs in Spain, Díaz, Caparrós and Sierra (2019) indicate that in various surveys conducted in their country, the majority of students surveyed $(40.5 \%)$ values as low or very low the level of scientific education this received. The authors noted that it is because the development of the classes is mainly directed towards the transmission of decontextualized content of the interests and needs of the student's reality; therefore, student participation is low, limited and with little impact on the development of their scientific thinking. They showed that, in schools, the literacy of science does not develop adequately, since they consider only the mere transmission of contends with respect to science; however, scientific literacy implies more than that, since a cynically literate student is able to face and make informed decisions in various situations of his day life related to science; therefore, the teaching-learning process has to be meaningful to students, it is to imply that his previous apprentices are considered, that the work is both practical and experimental and that the role of the teacher is that of a guide throughout the process.

According to the above, this article proposes two objectives: 1) to explain the evolution of the dimensions of scientific literacy in students from 10 to 15 years in the period 2000-2020 from the revision of literature; to meet this objective, it has been based on the International Student Assessment Programme (PISA), which is led by the Organization for Economic Co-operation and 
Development (OECD), $d$ is pisa's first assessment in 2000 until the last one in 2018; the dimensions evaluated in the area of science have evolved, these changes are the ones that will be presented throughout this article and 2) present theoretical proposals of methodological strategies to improve the level of development of scientific literacy in students from 10 to 15 years; to achieve this objective, it has been considered various strategies that are part of the so-called active methodology and that, in applying them in different researches, obtained positive results.

For all the above, this research will allow to extend the literature on scientific literacy, mainly, in students of the last cycle of the primary level and in high school students, since the studies or research that have been found on the subject are scarce and, at the same time,will allow to lay a basis for future research that seeks to deepen and contribute to an educational change.

\section{DEVELOPMENT}

\section{Definition of scientific literacy}

The concept of scientific literacy has been studied in too much, but the most accepted and widespread definition by the scientific community (Navarro and Ferster, 2012; Solaz y Selfa, 2016) is presented in the OECD-led ISA PTHAT that defines scientific literacy as follows:

The ability to use scientific knowledge to identify questions and draw conclusions based on evidence, in order to understand and help make decisions about the natural world and the changes made to it through human activity (Harlen, 2002, p. 210).

\section{Evolution of scientific literacy societies from PISA 2000 to 2018}

Harlen (2002) provided an overview of the three dimensions of scientific literacy that are evaluated in PISA 2000: rhyme, we have the dimension of scientific processes, this refers to mental processes that are involved when addressing a question or topic. The second dimension is that of content, refers to scientific knowledge and understanding of concepts that are of vital importance in the use of processes. Finally, the dimension of contexts, understood as the situations in which processes and conceptual understanding are applied, for example, the personal context of health and disease or the overall context of the environment (OECD, 2002).

Dis pisa's first assessment in 2000 through 2018, the dimensions have evolved. According to the OECD (2002), in PISA 2000, in the dimension of scientific processes, five processes were evaluated: recognizing scientifically researchable questions, identifying the evidence needed in scientific research, designing or evaluating concluding, communicating invalid conclusions and demonstrating understanding of scientific concepts. In this regard, Rosales, Rodríguez and Romero (2020) stated that, in PISA 2003, the processes evaluated were three: understanding scientific research, interpretation of scientific evidence and conclusions, in addition to describing, explaining and predicting scientific phenomena, also report that, as of PISA 2006, this dimension was renamed "scientific competences "and, in the editions of PISA 2006, 2009 and 2012, the following competencies were assessed: identifying scientific issues, explaining scientific phenomena and using scientific evidence. Finally, in PISA 2015 and 2018, the competencies examined were three: evaluating and designing scientific research, explaining scientific phenomena and interpreting scientific data and evidence (OECD, 2017, 2019).

Table 1. Evolution of the scientific process dimension from PISA 2000 to 2018.

\begin{tabular}{cccc}
\hline \multicolumn{2}{c}{ Processes } & \multicolumn{2}{c}{ Competences } \\
\hline PISA 2000 & PISA 2003 & PISA 2006, 2009, 2012 & PISA 2015, 2018 \\
\hline $\begin{array}{l}\text { Recognize scientifically } \\
\text { researchable questions }\end{array}$ & Understanding scientific & Identifying scientific & Evaluate and design \\
scientific research
\end{tabular}


Identify the necessary evidence in scientific research

\begin{tabular}{cccc}
\hline Design or evaluate conclusions & $\begin{array}{c}\text { Interpretation of scientific } \\
\text { evidence and conclusions }\end{array}$ & Use scientific evidence & $\begin{array}{c}\text { Interpreting scientific } \\
\text { data and evidence }\end{array}$ \\
\cline { 1 - 3 } Communicate valid conclusions & $\begin{array}{c}\text { Describe, explain and } \\
\text { predict scientific } \\
\text { phenomena }\end{array}$ & $\begin{array}{c}\text { Explaining phenomena } \\
\text { scientific concepts }\end{array}$ & $\begin{array}{c}\text { Scientists } \\
\text { Demolaining phenomena } \\
\text { scientifically }\end{array}$
\end{tabular}

Source: Rosales et al. (2020).

With regard to the dimension of scientific content orknowledge, in PISA 2000 and 2003, the intention was not to identify all concepts that met this criterion, therefore only the following topics were selected: structure and properties of matter, atmospheric change, chemical and physical changes, energy transformations, forces and movement, form and function, human biology, physiological change, biodiversity, genetic control, ecosystems, Earth and its place in the universe and geological change (Harlen, 2002; OECD, 2002, 2004). In PISA 2006, 2009 and 2012, "scientific knowledge" refers to knowledge of science and knowledge about science; in the first type of knowledge, the contents were grouped into the following categories: physical systems, living systems, Earth systems and space and technological systems; in the second type, the categories were two: research and scientific explanations (OECD, 2006, 2009, 2013). In PISA 2015 and 2018, this dimension was divided into three types of knowledge: knowledge of content, understood as understanding the main concepts of science; procedural knowledge, relating to the practice of scientific research and, finally, epidemic knowledge that is related to the understanding of the nature of science (Rosales et al., 2020).

Table 2. Evolution of the dimension of content or scientific knowledge from PISA 2000 to 2018.

\begin{tabular}{|c|c|c|}
\hline \multicolumn{3}{|c|}{ Scientific content or knowledge } \\
\hline PISA 2000, 2003 & PISA 2006, 2009, 2012 & PISA 20015, 2018 \\
\hline The contents were grouped into the & knowledge: & knowledge: \\
\hline following major topics: & - Physical systems & - Physical systems \\
\hline 1. Structure and properties of matter & - Systems of Earth and space & - Living systems \\
\hline 2. Atmospheric change & - Technological systems & - Earth and space systems \\
\hline 3. Physical and chemical changes & Consociation about science: & knowledge or procedural: \\
\hline 4. Energy transformations & - Scientific research & it is necessary to par with the \\
\hline 5. Forces and movement & - Scientific explanations & practice of scientific research. \\
\hline 6. Shapes and functions & & Epistemic consociation: \\
\hline 7. Human biology & & refers to understanding the role \\
\hline 8. Physiological change & & of constructs and characteristics \\
\hline 9. Biodiversity & & essential to the process of \\
\hline 10. Genetic control & & building scientific knowledge. \\
\hline 11. Ecosystems & & \\
\hline 12. The Earth and its place in the universe & & \\
\hline 13. Geological change & & \\
\hline
\end{tabular}

The third dimension is that of scientific contexts or s, as already mentioned, refers to the situations in which processes can be applied and the understanding of concepts in relation to realworld issues, based on this, in PISA 2000 and 2003, the following spaces of application were defined: science in life and health, science on Earth and the environment and science in technology. The problems in these spaces or areas are relevant in the personal, community, global and historical context (OECD, 2002, 2004). Subsequently, from PISA 2006 to PISA 2018, five areas of application were defined: health, natural resources, environment, risks and frontiers of science and technology; and the contexts were: staff (family and close friends), social (community) and global (OECD, 2006, 2009, 2013, 2017). 
Table 3. Evolution of the dimension of scientific contexts or situations from PISA 2000 to 2018. PISA 2000, 2003 PISA 2006, 2009, 2012, 2015, 2018

\begin{tabular}{ccc}
\hline $\begin{array}{c}\text { Situations or } \\
\text { contexts }\end{array}$ & Personal, community, global and historical & Personal, social and global \\
\hline $\begin{array}{c}\text { Areas of } \\
\text { application }\end{array}$ & $\begin{array}{r}\text { Science in life and health } \\
\text { Scien theT ierra and the environment } \\
\text { Science in technology }\end{array}$ & $\begin{array}{c}\text { Natural resources } \\
\text { Medio ambiente } \\
\text { Risks }\end{array}$ \\
\end{tabular}

From PISA 2006 to PISA 2018, to the three dimensions already developed, the dimension of "attitudes" is added, this refers to showing interest or attention to the science, supporting scientific research and being motivated to act responsibly; for example, with environmental care (OECD, 2006). Acevedo (2007) stated that promoting interest in science issues in students has become a fundamental object of education; itis still noted that, in schools, the teaching of scientific content continues to be prioritized; that is, it seeks to provide students with an extensive background of scientific knowledge and the affective aspect of the actinal dimension is set aside. As a result, scientific education is declining markedly, as science-related careers are in low demand and also a frequent drop-out of studies early or mid-career. For this reason, it is essential to attach the necessary importance to this dimension.

\section{Levels of scientific literacy}

To evaluate scientific literacy, five levels were established, according to Bybee (1997): 1) scientific illiteracy, the peculiarity at this level is that students have a decreased cognitive ability or limited use of scientific concepts. The number of discs at this level should be minimal; 2) nominal scientific literacy, here students understand or distinguish questions, concepts or scientific topics, although their knowledge is characterized by misconceptions; (3) functional and technological scientific literacy is characterized by the use of scientific and technological concepts in specific situations; for example, when defining abrash in a written assessment; however, they have a superficial understanding of this knowledge; 4) conceptual and procedural scientific literacy, for this level it is hoped that the discs will not only understand scientific concepts, they must also understand the overalled of this discipline, with its research methods and procedures. Procedural knowledge and skills are essential for both scientific research and technology-related problem solving and 5) multidimensional scientific literacy, at this level of literacy, in addition to understanding the scientific, philosophical, historical and social dimensions are added with respect to the scientific and technological field. Students establish relationships within scientific disciplines, as well as between science and technology. The author mentions that this level is not reached in schools and even that scientists reach this level is somewhat unusual (quoted by Navarro \& Ferster, 2012; Manchego, 2019).

Table 4. Levels of scientific literacy.

\begin{tabular}{ccccc}
\hline Scientific illiteracy & $\begin{array}{c}\text { Nominal scientific } \\
\text { literacy }\end{array}$ & $\begin{array}{c}\text { Functional and } \\
\text { technological } \\
\text { scientific literacy }\end{array}$ & $\begin{array}{c}\text { Conceptual and } \\
\text { procedural } \\
\text { scientific literacy }\end{array}$ & $\begin{array}{c}\text { Multidimensional scientific } \\
\text { literacy }\end{array}$ \\
\hline $\begin{array}{c}\text { Limited use of } \\
\text { scientific concepts. }\end{array}$ & $\begin{array}{c}\text { They can } \\
\text { distinguish } \\
\text { scientific concepts, }\end{array}$ & $\begin{array}{c}\text { They employ } \\
\text { scientific and } \\
\text { technological }\end{array}$ & $\begin{array}{c}\text { They understand } \\
\text { the globality of } \\
\text { scientific discipline. }\end{array}$ & $\begin{array}{c}\text { They comprise } \\
\text { philosophical, historical } \\
\text { and social dimensions with }\end{array}$ \\
\hline
\end{tabular}


but with

misconceptions. concepts in specific

situations. respect to the scientific

field.

\section{Methodological strategies to improve the development of scientific literacy}

Today, with the constant changes that society undergoes and the continuous advancement of technology, in addition to the multiple benefits that scientific knowledge brings to society at large, many countries have chosen to implement to their national curriculum the approach of scientific literacy (Navarro \& Ferster, 2012; Wang et al., 2019) in order to shape students to become active, participatory and critical citizens of the reality in which they unfold (Winarni et al., 2020).

To achieve this objective, the role of the teacher is fundamental at all levels of education, due to the indispensable role they play in the preparation of people with scientific knowledge (Al Sultan et al., 2018). On the other hand, many teachers do not apply the appropriate methodologies to generate meaningful learning in their students and, as has been demonstrated indifferent studies, conceptual knowledge is followed; that is, the memorization of content, which only causes students to have difficulty applying the knowledge acquired in the school in their daily life (Jufrida et al., 2019). In the face of this, Mendoza and Barreto (2017) confirmed that the activities that arise in the school should lead the student to the approach of questions, problems and alternatives of solution; but considering the environment, the needs and interests of each. In this regard, it is necessary to change traditional teaching strategies; for this reason, some methodological strategies will be released that have achieved good results during their application in different researches.

As a first strategy, we have learning by discovery with the use of ICT, carried out in research conducted by Winarni et al. (2020); in this learning, students build their learning through research or resolutions of teacher-led problems, and if this strategy is added to the use of ICT, it becomes even more effective, because it will attract the attention of students who, currently, are very immersed in technology, thus creating an active and pleasant learning space, motivating students to participate individually or as a team.

The second strategy is learning based on investigation (ABI) or also called indexation learning (Romero, 2017). For Bevins and Price (2016), the indexation "gives students greater control over their own learning and allows them to actively navigate paths that increase their understanding, motivation and improve their attitude towards scientific practice" (Romero, 2017, p. 289), which leads to educated increasing their self-esteem and ability to handle new information. Under the same line, in a research work carried out by Manchego (2019), after the application of an entrance test, it was observed that the total number of students, who were divided into control group and experimental group, was at the levels of initiation and process of scientific literacy. After applying the research-based learning strategy with the students of the experimental group, an exit test was conducted and the results showed that only $36.7 \%$ of the control group managed to achieve the expected and outstanding level of achievement, while $96.7 \%$ the experimental group achieved these same levels. It was therefore achieved as a result that this strategy positively influenced the development of scientific literacy in high school fourth graders. In addition, based on the results of the author, it is recommended that the $A B I$ be implemented at all levels of education.

Finally, learning based on projects ( $A B P)$, in this teaching-learning strategy, the discs are the protagonists of the construction of their own learning, since, when developing a project, a series of knowledge, actions, interactions and resources are put into practice to solve real problems of society (Martí et al., 2010; Medina \& Tapia, 2017). An example of the application of this stratum is the Zientzia live project, whose objective is to scientifically literate the project participants, this research was carried out by Garmendia \& Guisasola (2015), the workshops that were held in this project are typical of a non-formal context, this means that they do not obey a curriculum and therefore do not have a formal evaluation. However, they are very helpful in verifying students' learnings. The results obtained show that the students liked all the experiments and workshops 
carried out during the project, mainly, in which they can participate directly or those that generate surprise. It is also shown that they met their objective of scientifically literacy on the topics presented in the workshop.

\section{METHODOLOGY}

For research, was used databases such as Scielo, Eric, Redalyc, Alicia, Dialnet and the official OECD website. In addition, the information collected is from research carried out from 2000 to 2020. The strategy used for information collection consisted of keyword use, word trick, topic and recommended author. As a result, a total of 40 articles were obtained that were evaluated by criteria of inclusion (such as relevance, validity, reliability and contributions) and exclusion (as unfinished information, did not correspond to the poblstudy, among others). As a result, 17 articles remained, plus 7 reports of the theoretical framework of the PISA test, all these documents were used for the development of this research work. Of the 24 Documents analyzed, 16 are in Spanish language and 8, In English. In addition, for its elaboration, was made research in the following countries: Spain, Peru, Chile, Ecuador, Colombia, Portugal, China, FinlandIndonesia and Turkey. What most artyculwere made in Spain means that the issue ofScientific literacy is being further investigated in this country. As for the method, this was a bibliographic review, which, according to Gómez et al. (2014), ensures that the most relevant information is obtained from the subject of study, after the review of a significant amount of Extensive docuMentos. Also refers that we can find the information in different formats such as books, magazines, technical reports, thesis, among others. About the steps review begins with the introduction, which contains the objectives, justification and background of the review work. The development was then developed, which presents the most relevant aspects of the theme and the author's own ideas. The methodology was then drafted, which contains the databases, strategy, method and characteristics of the articles consulted. Finally, the conclusions and the briefly showing the scope of this work.

Figure 1. Methodology summary.

\begin{tabular}{|c|c|}
\hline Method & Bibliographical review. \\
\hline Databases & $\begin{array}{c}\text { Scielo, Eric, Redalyc, Alicia, Dialnet and the } \\
\text { official OECD website. }\end{array}$ \\
\hline Search strategies & Keywords, word trick, theme and author. \\
\hline Languages & $\begin{array}{c}16 \text { articles are presented in Spanish and 8, in } \\
\text { English. }\end{array}$ \\
\hline
\end{tabular}

\section{CONCLUSION}

First, it is important to develop scientific literacy in students, as this capacity will equip them with the scientific knowledge necessary to be better prepared and can both face and seek solutions to the problems presented to them in the real world. In addition, they will contribute to the social and economic development of society.

With regard to the dimensions of scientific literacy, it isinfied that scientific processes are the dimension that has had the most changes in each of PISA's assessments compared to the others. The most significant change that is presented is the name, since, from PISA 2006, this dimension was renamed "scientific competences". 
In the dimension of content or scientific knowledge, it follows that the type of knowledge that ismost evaluated in PISA tests is conceptual, because it has more questions in relation to the other types. This may be due to the way the evaluation is given, as students only answer questions using a written paper or through a computer; therefore, it becomes difficult to assess procedural and epidemic knowledge, since it involves much more than just mastering or knowing scientific laws, theories or concepts, it becomes necessary to work experimentally with students to make them the builders of their learning themselves. For this reason, it is essential that, in order to train scientifically literate students, all three types of knowledge go hand in hand.

With regard to scientific contexts, it is important that, when developing scientific subjects, all student contexts (personal, social and global) are considered, as there are topics or problems, such as pollution, that are affecting the three contexts; that is why it is vital that students are prepared to be able to face these problems and seek various alternatives of solution based on the knowledge they have obtained. Moreover, the historical context should not be set aside, because it is substantial to know the Cambio that science has experienced over the years.

The dimension of attitudes, even if it has not been evaluated since the first editions of the PISA program, is charging remarkable importance, as it is essential that students are interested and motivated to learn science, only in this way will the learning they obtain be meaningful and therefore lasting.

On the other hand, itis a fact that a traditional teaching still persists within the classrooms, which evidently does not generate a motivation to learn in students. Therefore, it is essential to work with new methodological strategies to motivate students and, in this way, improve their levels of scientific literacy development. To this end, after the bibliographic review it is recommended to apply the following strategies: (a)discovery learning through the use of ICT, research-based learning and project-based learning. In addition to generating motivation in students, these strategies are very useful for working at all levels of education from initial to the upper level.

Finally, to address scientific literacy, the research line of "Didactics of Natural Sciences" is proposed, because it proposes research on the initial and continuous training of science teachers and on the teaching-to-learning strategies of them.

Authors' Contributions: Colonia, S. C.: conception and design, acquisition of data, analysis and interpretation of data, drafting the article, critical review of important intellectual content; Fuster-Guillén, D.: conception and design, acquisition of data, analysis and interpretation of data, drafting the article, critical review of important intellectual content; Castro, A. S.: conception and design, acquisition of data, analysis and interpretation of data, drafting the article, critical review of important intellectual content; Leyva, H. W. M.: conception and design, acquisition of data, analysis and interpretation of data, drafting the article, critical review of important intellectual content; Ramírez, T. V. C.: conception and design, acquisition of data, analysis and interpretation of data, drafting the article, critical review of important intellectual content. All authors have read and approved the final version of the manuscript.

Ethics Approval: Not applicable.

Acknowledgments: Not applicable.

\section{REFERENCES}

Acevedo, J. (2007). Las actitudes relacionadas con la ciencia y la tecnología en el estudio PISA 2006. Revista Eureka sobre Enseñanza y Divulgación de las Ciencias, 4(3), 394-416.

Al Sultan, A., Henson, H. y Fadde, P. (2018). Pre-Service Elementary Teachers' Scientific Literacy and Self-Efficacy in Teaching Science. IAFOR Journal of Education, 6(1), 25-41.

Brito, R. S., Prado, J. R., \& Nunes, C. P. (2017). As condições de trabalho docente e o pós-estado de bem-estar social. Revista Tempos e Espaços em Educação, 10(23), 165-174. https://doi.org/10.20952/revtee.v10i23.6676 
Díaz, N. (2019). Caracterizando controversias sociocientíficas en la prensa escrita. Una herramienta para el desarrollo de la alfabetización científica. Revista Eureka sobre Enseñanza y Divulgación de las Ciencias, 16(1), 1102.

https://doi.org/10.25267/Rev Eureka ensen divulg cienc.2019.v16.i1.1102

Díaz, N., Caparrós, E. y Sierra, E. (2019). Las controversias sociocientíficas como herramienta didáctica para el desarrollo de la alfabetización científica. International Journal of Educational Research and Innovation (IJERI), 12, 261281.

Garmendia, M. y Guisasola, J. (2015). Alfabetización científica en contextos escolares: El Proyecto Zientzia Live! Revista Eureka sobre Enseñanza y Divulgación de las Ciencias, 12(2), 294-310.

Gómez, E., Fernando, D., Aponte, G. y Betancourt, L. (2014). Metodología para la revisión bibliográfica y la gestión de información de temas científicos, a través de su estructuración y sistematización. Dyna, 81(184), 158-163.

Harlen, W. (2002). Evaluar la alfabetización científica en el programa de la OECD para la evaluación internacional de estudiantes (PISA). Enseñanza de las ciencias, 20(2), 209-216.

Jufrida, J., Basuki, F., Kurniawan, W., Pangestu, M. y Fitaloka, O. (2019). Scientific literacy and science learning achievement at junior high school. International Journal of Evaluation and Research in Education (IJERE), 8(4), 630. https://doi.org/10.11591/ijere.v8i4.20312

Manchego, J. (2019). Influencia del aprendizaje basado en investigación en el desarrollo de la alfabetización científica en estudiantes de Educación Secundaria de la I.E.P San José (tesis doctoral). Universidad San Martin de Porres, Lima, Perú.

Martí, J., Heydrich, M., Rojas, M. y Hernández, A. (2010). Aprendizaje basado en proyectos: una experiencia de innovación docente. Revista Universidad EAFIT, 46(158), 11-21.

Medina, M. y Tapia, M. (2017). El aprendizaje basado en proyectos una oportunidad para trabajar interdisciplinariamente. OLIMPIA. Revista de la Facultad de Cultura Física de la Universidad de Granma, 14(46), 236246.

Mendoza, C. y Barreto, C. (2017). El aprendizaje por indagación hacia la alfabetización científica de los estudiantes en la I.E. no. 3 Santa Catalina de Siena de Maicao- La Guajira. Bio-grafía, 10(19), 1238-1246.

https://doi.org/10.17227/biografia.extra2017-7296

Navarro, M. y Förster, C. (2012). Nivel de alfabetización científica y actitudes hacia la ciencia en estudiantes de secundaria: comparaciones por sexo y nivel socioeconómico. Pensamiento Educativo. Revista de Investigación Educacional Latinoamericana, 49(1), 1-17.

OCDE (2002). Muestra de reactivos empleados en la evaluación PISA 2000. aptitudes para lectura, matemáticas y ciencias. México: Editorial Santillana.

OCDE (2004). Marcos teóricos de PISA 2003: la medida de los conocimientos y destrezas en matemáticas, lectura, ciencias y resolución de problemas / OCDE. Madrid: Ministerio de Educación y Ciencia, Instituto Nacional de Evaluación y Calidad del Sistema Educativo.

OCDE (2006). PISA 2006. Marco de la evaluación. Conocimientos y habilidades en ciencias, matemáticas y lectura. Madrid: Santillana Educación.

OCDE (2009). PISA 2009. Assessment framework-key competencies in reading, mathematics and science. Paris: OCDE. OECD (2013). PISA 2012 Assessment and Analytical Framework: Mathematics, Reading, Science, Problem Solving and Financial Literacy, OECD Publishing. http://dx.doi.org/10.1787/9789264190511-en

OECD (2017). PISA 2015 Assessment and Analytical Framework: Science, Reading, Mathematic, Financial Literacy and Collaborative Problem Solving, revised edition, OECD Publishing, Paris. http://dx.doi.org/10.1787/9789264281820-en

OECD (2019). PISA 2018 Assessment and Analytical Framework, PISA, OECD Publishing, Paris, https://doi.org/10.1787/b25efab8-en.

Romero, M. (2017). El aprendizaje por indagación: ¿existen suficientes evidencias sobres sus beneficios en la enseñanza de las ciencias? Revista Eureka sobre Enseñanza y Divulgación de las Ciencias, 14(2), 286-299.

Rosales, E., Rodríguez, P. y Romero, M. (2020). Conocimiento, demanda cognitiva y contextos en la evaluación de la alfabetización científica en PISA. Revista eureka sobre enseñanza y divulgación de las ciencias, 17(2), 1-22.

https://doi.org/10.25267/rev_eureka_ensen_divulg_cienc.2020.v17.i2.2302 
Solaz, J. y Selfa, B. (2016). Estudio exploratorio de la asimilación de conceptos básicos en la alfabetización científica: el caso de un centro de educación secundaria público. Revista de Pedagogía, 37(100), 91-109.

Silva, L. R., Santos, A. R., \& Santos, I. T. R. (2020). Public policies for education of/in the field and the school environment in a settlement of the MST: the intimate relationship with the pedagogical policy. Journal of Research and Knowledge Spreading, 1(1), e11737. http://dx.doi.org/10.20952/jrks1111737

Wang, Y., Lavonen, J. y Tirri, K. (2019). An assessment of how scientific literacy-related aims are actualised in the National Primary Science curricula in China and Finland. International Journal of Science Education, 41(11), https://doi.org/10.1080/09500693.2019.1612120

Winarni, E., Hambali, D. y Purwandari, E. (2020). Analysis of Language and Scientific Literacy Skills for 4th Grade Elementary School Students through Discovery Learning and ICT Media. International Journal of Instruction, 13(2), 213-222. https://doi.org/10.29333/iji.2020.13215a

Received: 11 March 2021 | Accepted: 22 April 2021 | Published: 1 May 2021

This is an Open Access article distributed under the terms of the Creative Commons Attribution License, which permits unrestricted use, distribution, and reproduction in any medium, provided the original work is properly cited. 